BJHS, 1998, 31, 107-123

\title{
British Society for the History of Science
}

\section{Report of Council for the year 1996}

\author{
INTRODUCTION
}

Objects

The primary objective for which the Society is established is to promote and further the study of the history and philosophy of science. Secondary objectives include the provision of facilities, the arrangement of meetings, the promotion of research and the publishing of papers; full details of all the objectives may be found in the Society's Memorandum of Association.

\section{Policies}

The main policy of the Society is to provide the infrastructure to gain its objectives and in approved cases to provide financial assistance by which its members and others may benefit in some aspect of their activities while helping to achieve the objects of a learned Society.

To achieve this overall policy, the Society maintains a world-wide membership, issues several publications, chief of which is the British Journal for the History of Science, holds regular meetings and conferences on the history of science, technology and medicine, and contributes where appropriate to debate at governmental and other levels on scientific and educational issues.

In terms of direct financial benefits, membership for students, the retired and the unemployed is subsidized, and reduced charges and bursaries are available for students attending conferences. Conferences are frequently assisted in some degree. Travel, especially to overseas meetings, is often met for individual members and others out of Society funds. There is a biennial essay competition open to members and non-members, the winner of which is awarded the Singer Prize. Several publications are issued free to both members and non-members, while members enjoy reduced charges for some publications.

There have been no material changes to the policy of the Society since the last report. With a view to celebrating the fiftieth Anniversary of the founding of the Society, its Council has developed plans to establish a biennial Book Prize to be named after Herbert Dingle, a founder member of the Society. Council has also considered the creation of an Anniversary Fellowship for work on the history of the history of science in Britain. The Anniversary was celebrated at a meeting in Leeds in September 1997. 


\section{Organization}

The controlling body of the Society is its Council. Several sub-committees are responsible to Council for various activities (see below) and several members of Council have an Officer post designated for a specific responsibility. Council is advised by a number of Advisory Officers in specialist roles and by the Executive Secretary. The Executive Secretary is also the Company Secretary and he is responsible for the day-to-day administration of the Society, including keeping the accounts. The Executive Secretary is under contractual terms, reviewed annually by Council. No member of Council or the Society receives any remuneration for services to the Society but expenses are paid.

\section{REVIEW OF ACTIVITIES}

\section{Extraordinary General Meeting}

At the EGM held at the Modern History Faculty, Broad Street, Oxford, on 12 June 1996, the following Officers and Ordinary Members of Council were appointed for the year 1996-97:

Officers

President Professor John H. Brooke

Vice-President Professor David M. Knight

Secretary

Dr Jeff Hughes

Programme Secretary Dr Jon Agar

Treasurer

Dr Mari E. W. Williams

Editor

Dr E. Janet Browne

Newsletter Editor

Dr Frank A. J. L. James

External Affairs Officer

Dr David E. H. Edgerton

Ordinary Members

Dr Sophie Forgan

Dr Sally M. Horrocks

Professor John S. Rowlinson

Dr Graeme J. N. Gooday

Dr Penelope M. Gouk

Professor Martin J. Kemp

Dr Alan Q. Morton

Dr Liba C. Taub

Dr Katherine D. Watson

\section{Other meetings}

\section{Graduate Student Meeting, 5-6 January 1996, Imperial College, London}

Organized jointly with the South Kensington Institute for the History of Science and Technology by Dr R. Iliffe and Dr A. Morton, this meeting gave graduate students the opportunity to present papers on their work. They were also given guided tours of the exhibitions and stores of the Science Museum to show the resources available for researchers in the history of science and technology. Papers were delivered by D. Boughey, D. Cox-Maximov, J. Fisher, L. Gurjeva, J. Kennedy, D. M. Knight, F. Neary, S. Nightingale, C. Sichau and A. Yoshioka. 
2. Archives of the Scientific Revolution, 11-12 April 1996, Royal Society, London

This meeting, organized by Professor Michael Hunter jointly with the Royal Society, attempted to enhance our understanding of the Scientific Revolution by considering the archives that have come down to us from it as artefacts in their own right. It considered the Collezione Galileiana and the Hartlib papers, the manuscripts of Elias Ashmole, Ismael Bouillau, Robert Boyle, Christiaan Huygens, G. W. Leibniz, Isaac Newton and William Petty; and the collections of the Académie des Sciences and the Royal Society. Papers were delivered by D. Bertoloni Meli, M. Bucciantini, C. Demeulenaire-Douyere, M. Feingold, R. Goulding, M. Greengrass, D. Harley, F. Harris, R. Hatch, M. Hunter, R. Iliffe, J. Milton, F. Nagel, J. O’Hara, M. Sampson, D. Sturdy and J. Yoder.

3. Images and Practice, 12 June 1996, Modern History Faculty, Museum of the History of Science and Ashmolean Museum, Oxford

This meeting, organized by Dr J. Bennett and Dr S. Johnston, considered issues of representation in the history of science. It moved between three sites, exploiting the rich resources available for history of science in Oxford. In the first session, contributions were made by J. Bennett, W. Hackmann, M. Kemp and S. Johnston. The second session consisted of a viewing of the special exhibition 'Geometry and War, 1500-1750', at the Museum of the History of Science. The meeting concluded with a paper by L. Jordanova on 'Historians and their Images'.

\section{Third British - North American Joint Meeting: 'Crossing Boundaries', 23-26 July 1996, Edinburgh}

This meeting was organized jointly with the History of Science Society and the Canadian Society for the History and Philosophy of Science (Dr J. Henry acted as local organizer on behalf of the BSHS, while Professor D. Knight, Dr S. Pumfrey, Dr J. Henry and Dr S. Horrocks constituted a BSHS Programme Committee; Professor R. Hatch represented the HSS and Professor Hannah Gay represented the CSHPS; Dr R. Bud acted as SHOT liaison). The meeting explored the theme 'Crossing Boundaries' from a wide variety of perspectives and also sustained a varied and successful social programme.

Papers were given by T. Alborn, K. Anderson, R. Ashcroft, T. Ballantyne, R. Baum, K. Benson, A. Blair, T. Boon, H. J. M. Bos, M. Boumans, S. Brauckmann, M. Bravo, S. Brentjes, L. M. Brown, D. Cahan, A. Carneiro, N. Chaigneau, P. Champlin, J. A. Charbonneau, P. Chavot, A. Clericuzio, G. Clifton, H. F. Cohen, J. Cohen, C. Comacchio, A. Cooper, L. Cormack, S. Cuomo, P. Dear, M. A. Dennis, M. P. Diogo, C. Divall, B. Dolan, A. D. Dreger, A. Ede, R. B. Ekelund, P. Eliasson, R. England, W. Ernst, J. Foster, R. M. Friedman, S. Fuller, Y. Gauthier, K. Gavroglu, D. Gooding, M. E. Gorman, M. J. Gorman, P. Gould, L. Gurjeva, B. Hacker, M. Harbsmeier, R. A. Hatch, R. Hayward, R. F. Hebert, T. van Helvoort, A. Hessenbruch, B. Hevly, K. Hill, P. Hoffenburg, J. R. Hofmann, K. Horstman, L. Howsham, K. Hufbauer, M. Hunter, R. Iliffe, M. Jackson, F. A. J. L. James, S. Jasanoff, A. Jenkins, A. Johns, S. Johnston, S. F. Johnston, R. Kargon, 
N. Kemmer, S. Kenen, D.-W. Kim, M. G. Kim, L. Koerner, K. Kurita, O. Lageux, W. J. Laird, S. E. Lederer, P. Le Gall, S. Leslie, S. J. Livesey, J. Loach, M. F. Low, H. Maas, R. MacLeod, G. McOuat, T. Malet, R. J. Malone, J. Mason, M. M. Meldrum, M. Morgan, M. Morrison, E. Muelhausen, K. Nier, M. Ogilvie, K. M. Olesko, M. Oster, P. Palladino, T. Porter, H. Rechenberg, R. E. Rice, M. Richmond, C. Rodine, S. R. Roff, N. Rogers, T. M. Romano, A. Rusnock, A. Samuel, S. Sangwan, M. Schabas, S. Schweber, A. Secord, J. A. Secord, D. M. Secoy, S. Sheets-Pyenson, A. Simoes, W. A. Smeaton, A. E. Smith, S. Soerlin, R. Sorrenson, M. Frasca Spada, E. C. Spary, R. Smith, R. W. Smith, T. Soederqvist, J. Stenhouse, L. Stewart, D. Strauss, S. Sturdy, A. Suzuki, M. Teall, J. Topham, S. Traweek, M. Trumpler, R. Tweney, A. Warwick, B. Weber, K. E. Wetmore, P. White, A. Winter, C. Withers, U. Wrakberg, D. Wright and S. Zeller.

5. Semaphores to Short Waves, 29 July 1996, Royal Society of Arts, London

Organized jointly with the Newcomen Society and the Royal Society of Arts, and sponsored by Cable and Wireless plc, this meeting commemorated the 150th anniversary of the incorporation of the Electric Telegraph Company. Papers were delivered by B. Bowers, J. D. Brown, A. Chapman, E. F. Clark, F. James, B. Hunt, J. Packer, V. D. Perkins and D. Read.

\section{Publications}

Four issues (volume 29, parts 1-4) of the British Journal for the History of Science were published under the editorship of Dr Janet Browne. The Journal is sent to members as part of the subscription benefit and is published separately at $£ 83$ (UK) and $\$ 144$ (overseas). Dr Frank A. J. L. James produced three issues of the Society's Newsletter during the year (Nos. 49, 50 and 51). The Newsletter is free to members, and is available to non-members at $£ 8(\$ 15)$ per year. Dr Sophie Forgan compiled the twenty-seventh List of Theses in History of Science (1996-97). The List, which is free to members, is available at $£ 6$ ( $\$ 11$ ) to non-members. Dr Janet Browne compiled the fourth edition of the Guide to History of Science Courses in Britain. The Guide is free to members and non-members. Dr Isobel Falconer edited three issues of the Education Section's newsletter Education Forum during the year (Nos. 18, 19 and 20). Forum is free to members and non-members.

The following monographs are currently available:

D. Outram (ed.), The Letters of Georges Cuvier: A Summary Catalogue - $£ 4.50$ ( $£ 3.50$ to members)

B. Wynne, Rationality and Ritual: The Windscale Inquiry and Nuclear Decisions in Britain - $£ 7.00$ ( $£ 5.00$ to members)

M. Hunter, The Royal Society and its Fellows, 1600-1700: The Morphology of an Early Scientific Institution, 2nd edn $-£ 10.00$ ( $£ 8.00$ to members)

G. Rees, with C. Upton, Francis Bacon's Natural Philosophy: A New Source - £7.90 ( $£ 5.60$ to members)

P. Morris and C. A. Russell, Archives of the British Chemical Industry, 1750-1914: A Handlist $-£ 14.50$ ( $£ 9.00$ to members) 
S. Sheets-Pyenson, Index to the Scientific Correspondence of John William Dawson$£ 20.00$ ( $£ 12.00$ to members)

M. Shortland (ed.), Science and Nature: Essays in the History of the Environmental Sciences - $£ 10.00$ ( $£ 8.00$ to members)

M. Crosland, In the Shadow of Lavoisier: The 'Annales de Chimie' and the Establishment of a New Science - $£ 9.00$ ( $£ 7.50$ to members)

J. Lester (ed. P. J. Bowler), E. Ray Lankester and the Making of Modern British Biology $-£ 9.00$ ( $£ 7.50$ to members)

\section{Membership}

From 1 January 1996, the annual membership subscription was raised to $£ 24$ (\$48) for Ordinary Membership, and $£ 12$ (\$25) for Associate Membership in Student, Retired and Unemployed grades. There are lower rates for those who do not take the Journal, and there is an Introductory Offer at $£ 20$ (\$40) for new Ordinary Members.

The following table summarizes changes in membership during 1996:

\begin{tabular}{lcc}
\hline \hline & As at 31 Dec 95 & As at 31 Dec 96 \\
\hline Ordinary Members & 652 & 613 \\
Associate Members & 61 & 59 \\
$\quad$ Student & 106 & 114 \\
Retired & 17 & -20 \\
Unemployed & & 806 \\
Total & 836 & \\
\hline \hline
\end{tabular}

There were fifty-one new members during 1996. It is with deep regret that Council records the deaths of Mr H. G. L. Bevan (a member since 1961) and Professor A. C. Crombie (a former President from 1964 to 1966).

The following information giving the number of members in each country is derived from the members' postal addresses as at 31 December 1996:

\begin{tabular}{|c|c|c|c|c|c|}
\hline United Kingdom & 440 & Republic of Ireland & 5 & Austria & 1 \\
\hline USA & 182 & Sweden & 5 & Croatia & 1 \\
\hline Germany & 30 & Greece & 4 & Egypt & 1 \\
\hline Canada & 24 & Portugal & 4 & Finland & 1 \\
\hline Australia & 16 & India & 3 & Hungary & 1 \\
\hline Japan & 16 & Korea & 3 & Israel & 1 \\
\hline France & 13 & Switzerland & 3 & Mexico & 1 \\
\hline The Netherlands & 12 & Denmark & 2 & Pakistan & 1 \\
\hline Italy & 11 & Luxembourg & 2 & Poland & 1 \\
\hline Spain & 11 & New Zealand & 2 & South Africa & 1 \\
\hline Belgium & 5 & Norway & 2 & Taiwan & 1 \\
\hline
\end{tabular}


Council

The Council of the Society met on three occasions: 21 January, 19 April and 20 September (all in London). The sub-committees and Advisory Officers of Council were as follows:

1. Programme Committee: Dr J. Agar, Dr S. Pumfrey, Professor J. H. Brooke, Professor D. M. Knight, Professor J. V. Pickstone.

2. Editorial Board: Dr E. J. Browne, Professor J. H. Brooke, Dr R. Bud, Dr P. Corsi, Professor O. Hannaway, Dr J. Henry, Professor M. Hunter, Professor L. Jordanova, Professor D. Lindberg, Dr D. Outram, Dr S. Pumfrey, Dr M. Shortland, Dr R. Yeo.

3. Finance Committee: Dr M. E. Williams, Professor D. M. Knight, Professor J. H. Brooke, Dr P. M. Collins.

4. External Affairs Committee: Dr D. Edgerton, Dr J. Hughes, Dr F. A. J. L. James, Professor D. M. Knight, Professor J. Rowlinson.

5. Education Section Committee: Mr P. R. Ellis (Chair), Mrs P. Burdett, Mrs M. Capel, Dr E. Crawford, Dr I. Falconer, Mr B. Sorsby, Dr C. Sutton, Dr R. Ward, Mr J. Williams.

6. Advisory Officers: Dr J. F. M. Clark (Monograph Series Editor), Mr P. R. Ellis (Chairman, Education Section Committee).

\section{Education Section}

The Education Section Committee met three times during the year under the chairmanship of Mr P. R. Ellis. Mr P. R. Rolleston resigned from the committee as he was moving to Ireland. The Section made its customary contribution to the ASE Annual Meeting at Reading University, with talks on Robert Boyle, Leonardo da Vinci and Augustus Harcourt, a history of technology workshop for primary school teachers and an exhibition.

\section{Administration}

This year has seen a major change in the presentation of the accounts in order to conform with the new regulations issued by the Charity Commissioners. The introduction of the Statement of Financial Activities is a positive step towards ensuring that the applications of the charity's resources can be clearly seen. There is nothing to add to the information already shown in the accounts but any person wishing to have a more detailed explanation should send the query to the Executive Secretary at the Registered Address. Council expresses its deep gratitude to the Executive Secretary, Wg Cdr Geoffrey Bennett, for administering the Society with characteristic efficiency, tact and good humour throughout the year.

G. Bennett

Executive Secretary and Company Secretary

J. Hughes

Director, Trustee and Honorary Secretary 


\section{Report of the Auditors for the year 1996}

To the Members of the British Society for the History of Science

We have audited the accounts on pp. 114-22.

Respective responsibilities of Council Members and Auditors

The Society's Council Members are responsible for the independent preparation of accounts. It is our responsibility to form an independent opinion, based on our audit, on those statements and to report our opinion to you.

\section{Basis of opinion}

We conducted our audit in accordance with Auditing Standards issued by the Auditing Practices Board. An audit includes examination, on a test basis, of evidence relevant to the amounts and disclosures in the accounts. It also includes an assessment of the significant estimates and judgements made by the Council Members in the preparation of the accounts and of whether the accounting policies are appropriate to the company's circumstances, consistently applied and adequately disclosed.

We planned and performed our audit so as to obtain all the information and explanations that we considered necessary in order to provide us with sufficient evidence to give reasonable assurance that the accounts are free from material misstatement, whether caused by fraud or error or other irregularity. In forming our opinion we also evaluated the overall adequacy of the presentation of information in the accounts.

\section{Opinion}

In our opinion the accounts give a true and fair view of the state of the company's affairs as at 3 December 1996 and of its surplus for the year then ended and have been properly prepared in accordance with the provisions of the Companies Act 1985.

Critchleys

Registered Auditors

Chartered Accountants

10 Marlborough Street

Faringdon, Oxon, SN7 7JP

April 1997 
STATEMENT OF FINANCIAL ACTIVITIES FOR THE YEAR ENDED 31 DECEMBER 1996

\begin{tabular}{|c|c|c|c|}
\hline & {$[$ Note $]$} & $\begin{array}{c}\text { Unrestricte } \\
\text { funds } \\
1996 \\
£\end{array}$ & $\begin{array}{c}1995 \\
£\end{array}$ \\
\hline \multicolumn{4}{|l|}{ Incoming resources } \\
\hline Membership subscriptions & & 17,728 & 19,263 \\
\hline British Journal for the History of Science & & 8,268 & 10,990 \\
\hline Other publications & & 3,327 & 2,422 \\
\hline Grants receivable & [2] & 2,500 & - \\
\hline Conferences & & 30,141 & 30,895 \\
\hline Investment income & & 4,468 & 3,938 \\
\hline Sale of rights & & - & 7 \\
\hline Total incoming resources & & 66,432 & 67,515 \\
\hline \multicolumn{4}{|l|}{ Resources expended } \\
\hline Direct charitable expenditure & [4] & 48,406 & 49,651 \\
\hline \multicolumn{4}{|l|}{ Other expenditure } \\
\hline Publicity & & 290 & 943 \\
\hline Management and administration & [6] & 13,188 & 11,759 \\
\hline Total other expenditure & & 13,478 & 12,702 \\
\hline Total resources expended & & 61,884 & 62,353 \\
\hline Net incoming resources & & 4,548 & 5,162 \\
\hline \multicolumn{4}{|l|}{ Gains on investment assets } \\
\hline Realized & & 86 & 1,663 \\
\hline Unrealized & & 5,106 & 9,054 \\
\hline Net movement in funds: & & 9,740 & 15,879 \\
\hline Fund balances brought forward & & 92,990 & 77,111 \\
\hline Fund balances carried forward & & $£ 102,730$ & $£ 92,990$ \\
\hline
\end{tabular}


SUMMARY INCOME AND EXPENDITURE ACCOUNT FOR THE

YEAR ENDED 31 DECEMBER 1996

Gross income of continuing operations

Total Total

19961995

Total expenditure of continuing operations

$£ \quad £$

$66,432 \quad 67,515$

$61,884 \quad 62,353$

Net income before investment asset disposal

$\overline{4,548} \quad \overline{5,162}$

Gain on disposal of fixed asset investments

$86 \quad 1,663$

Net income for the year

$£ 4,634 \quad £ 6,825$

The net income for the year has been calculated on the historical cost basis. 


\section{BALANCE SHEET AS AT 31 DECEMBER 1996}

[Note]

19961995

$£ \quad £$

Fixed assets

Tangible assets

$638 \quad 750$

Investments

$67,811 \quad 62,889$

$68,449 \quad 63,639$

Current assets

Stock

Debtors

Cash at bank

$3,485 \quad 3,649$

$11,709 \quad 14,859$

$25,988 \quad 20,843$

Creditors: amounts due within one year

$41,182 \quad 39,351$

$3,901 \quad 7,000$

Net current assets

$37,281 \quad 32,351$

Total assets less current liabilities

$\overline{105,730} \quad \overline{95,990}$

Net assets

$105,730 \quad 95,990$

Income funds

Designated funds

Other charitable funds

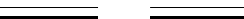

$$
\begin{aligned}
& 3,000 \quad 3,000 \\
& 102,730 \quad 92,990 \\
& \text { £ } 105,730 £ 95,990
\end{aligned}
$$

These accounts were approved on 26 April 1997 by Professor J. H. Brooke (President) and Dr M. E. W. Williams (Treasurer). 


\section{NOTES TO THE ACCOUNTS}

\section{[1] Accounting policies}

The financial statements have been prepared under the historical cost convention, as modified by the revaluation of investments, and are in accordance with applicable accounting standards and the Charities Accounting Statement of Recommended Practice (Sorp). There have been no changes in the accounting policies.

(a) Corresponding amounts: the corresponding amounts have been reanalysed to ensure consistency with the Sorp.

(b) All grants and voluntary income are accounted for gross when receivable, as long as they are capable of financial measurement. This includes gifts in kind, included at estimated valuation.

(c) All expenditure is accounted for gross, and when incurred.

(d) Direct charitable expenditure includes the direct costs of the activities and depreciation on related assets. Where such costs relate to more than one functional cost category, they have been split on either an estimate time or floor space basis, as appropriate.

(e) Support costs comprise service costs incurred centrally.

(f) Fixed assets are included at cost or valuation: there are no uncapitalized fixed assets.

(g) Depreciation is provided to write off the cost or valuation, less estimated residual values, of all fixed assets except freehold land, over their expected useful lives. It is calculated at the following rate: equipment and fittings $15 \%$.

(h) Stocks are valued at the lower of cost or net realizable value.

(i) Designated funds are amounts that have been set aside at the discretion of the trustees for a specific, but not legally binding, purpose.

(j) All investments are stated at market value.

[2] Grants receivable

\begin{tabular}{ccc} 
& 1996 & 1995 \\
Wellcome Trust & $£$ & $£$ \\
\hline & 2,500 & -
\end{tabular}

[3] Investments

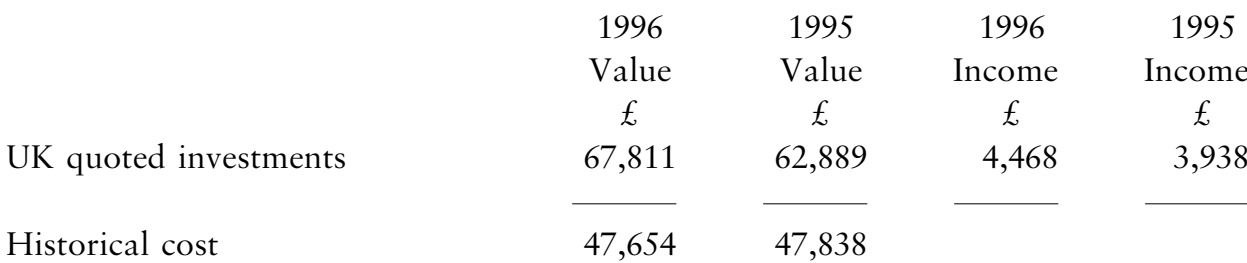


The value of investments allotted to ranges under the Trustee Investment Act as follows

$$
\begin{array}{lrr}
\text { Broad range } & 29,354 & 27,464 \\
\text { Narrow range } & 38,457 & 35,425 \\
& & \\
& 67,811 & 62,889
\end{array}
$$

The valuation of securities was undertaken by Branston and Gothard Limited, who are members of the London Stock Exchange and are regulated by the Securities and Futures Authority.

\begin{tabular}{|c|c|c|c|}
\hline Depreciation & Overheads & 1996 & 1995 \\
\hline$£$ & $£$ & $£$ & $£$ \\
\hline - & 884 & 884 & 858 \\
\hline - & 5,062 & 5,062 & 5,901 \\
\hline - & 33,672 & 33,672 & 32,788 \\
\hline 112 & 8,426 & 8,538 & 9,234 \\
\hline - & 250 & 250 & 870 \\
\hline 112 & 48,294 & 48,406 & 49,651 \\
\hline - & 290 & 290 & 943 \\
\hline - & 13,188 & 13,188 & 11,759 \\
\hline - & 13,478 & 13,478 & 12,702 \\
\hline
\end{tabular}

[4] Analysis of resources expended

Direct charitable expenditure:

Other expenditure:

Fund-raising and publicity

943

Management and

administration (note 6)

Total

\begin{tabular}{ccc}
1996 & 1995 \\
$£$ & & $£$ \\
7,564 & & 8,628 \\
974 & & 606 \\
\cline { 1 - 1 } & & \\
\hline 8,538 & & 9,234 \\
\hline
\end{tabular}

Office costs (including depreciation)

Bank and credit card charges 
[6] Management and administration costs

Audit fees

Executive Secretary commission and travel

Officers' expenses

Other

\begin{tabular}{ccc}
1996 & 1995 \\
$£$ & $\ldots$ \\
1,469 & & 1,116 \\
8,715 & & 8,254 \\
3,004 & & 2,240 \\
- & & 149 \\
\hline 13,188 & & 11,759 \\
\hline
\end{tabular}

[7] Tangible fixed assets

Fittings and

equipment

$£$

Cost or valuation:

As at 1 January 1996

and

As at 31 December 1996

Accumulated depreciation:

As at 1 January 1996

Charge for the year

As at 31 December 1996

Net book value at 31 December 1996

Net book value at 31 December 1995

The closing net book value repre-

sents fixed assets used for:

Direct charitable purposes

Management and administration 
[8] Debtors

\begin{tabular}{|c|c|}
\hline Entity & Entity \\
\hline 1996 & 1996 \\
\hline$£$ & $£$ \\
\hline 10,431 & 13,837 \\
\hline 933 & 939 \\
\hline 345 & 83 \\
\hline 11,709 & 14,859 \\
\hline
\end{tabular}

[9] Creditors: amounts falling due within one year

Due within one year

Trade debtors

Other debtors

Prepayments

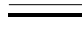

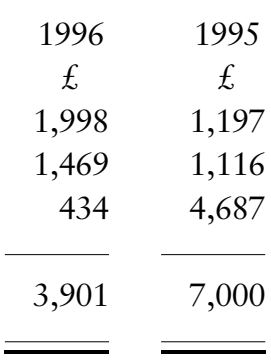

Trade creditors

Accruals

Deferred income

[10] Designated funds

\begin{tabular}{|c|c|c|c|c|}
\hline & $\begin{array}{c}\text { Opening } \\
\text { balance } \\
£\end{array}$ & $\begin{array}{c}\text { New } \\
\text { designations } \\
\ldots\end{array}$ & $\begin{array}{c}\text { Utilized/ } \\
\text { released } \\
£\end{array}$ & $\begin{array}{c}\text { Closing } \\
\text { balance } \\
£\end{array}$ \\
\hline Conference fund & 3,000 & - & - & 3,000 \\
\hline
\end{tabular}


[11] Analysis of net assets between funds

Fund balances at 31 December 1996 are represented by:

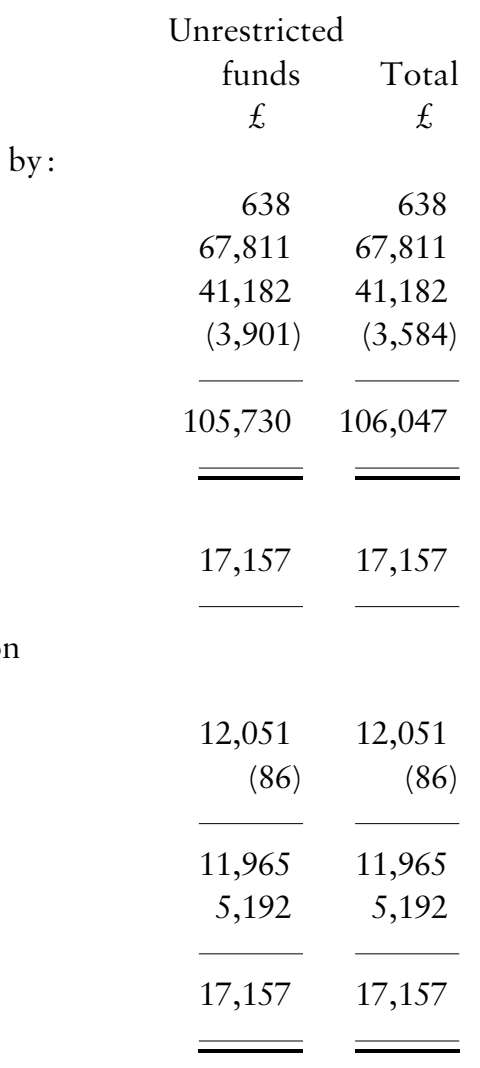

Tangible fixed assets

638

Investments

$\begin{array}{rr}67,811 & 67,811 \\ 41,182 & 41,182\end{array}$

Current assets

Current liabilities

Total net assets

Unrealizable gains included above

On investment assets

\author{
(n)
}

Reconciliation of movements in unrealizable gains on investment assets

Unrealized gains at 1 January 1996

Deduct in respect of disposals in year

Add: net gains arising on revaluations in year

Unrealized gains at 31 December 1996

[12] Officers' expenses

During the year the Officers received $£ 3,004$ for travelling costs $(1995-£ 2,240)$

\title{
[13] Members' liability
}

The company is limited by guarantee and does not have a share capital. The members undertake to contribute a sum, not exceeding $(£ 1)$, to the assets of the company in the event of the company being wound up. 
INCOME AND EXPENDITURE ACCOUNT FOR THE YEAR ENDED 31 DECEMBER 1996

Income

\begin{tabular}{|c|c|c|c|}
\hline \multicolumn{2}{|c|}{1996} & \multicolumn{2}{|c|}{1995} \\
\hline$£$ & $£$ & $£$ & $£$ \\
\hline & 17,728 & & 19,263 \\
\hline & 8,268 & & 10,990 \\
\hline & 1,439 & & 2,422 \\
\hline & 32,641 & & 30,895 \\
\hline & 3,771 & & 3,224 \\
\hline & - & & 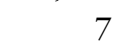 \\
\hline & 697 & & 714 \\
\hline & 64,544 & & 67,5 \\
\hline
\end{tabular}

Expenditure

British Journal for the History of Science $\quad 884 \quad 858$

Monographs (stock adjusted) $\quad 1,726 \quad 2,962$

$\begin{array}{lll}\text { Meetings } & 33,672 & 32,788\end{array}$

Grants $\quad$ - $\quad 520$

Postage, stationery, telephone and compu $\quad 6,374 \quad 7,941$

$\begin{array}{ll}\text { Audit and accountancy } & 1,469\end{array}$

Professional fees $\quad-\quad 149$

Other publications $\quad 542 \quad 1,676$

Newsletter $\quad 1,340 \quad 1,263$

Officers' expenses $\quad 3,004 \quad 2,240$

Publicity $\quad 290 \quad 943$

Storage, insurance and subscriptions $\quad 645 \quad 554$

Bank charges $\quad 81 \quad 103$

Credit card charges $\quad 892 \quad 503$

Singer prize $\quad 250 \quad 350$

(Profit) on sale of investment (86)

Executive Secretary commission and travel $\quad 8,715 \quad 8,254$

Depreciation $112 \quad 133$

Surplus for the year transferred to general fund $\quad \begin{array}{ccc}59,910 & 60,690 \\ & & =\end{array}$ 


\section{The British Society for the History of Science Ltd}

Report of the Directors

In accordance with Article 45 of the Articles of Association, Members of Council are the Directors of the Company by which the Society is known for purposes of registration under Company Law. This Report of Council is the Report of the Directors for the year 1996.

\section{Report of the Trustees}

In accordance with Article 45 of the Articles of Association, Members of Council are the Trustees of the Registered Charity by which the Society achieves its charitable objectives. The Report of Council is the Report of the Trustees for the year 1996.

\section{Responsibility for accounts}

As Directors and Trustees, Members of Council are required to prepare accounts for each financial year that give a true and fair view of the state of affairs of the company and the charity for that year. In preparing those accounts, the Members of Council are required to select suitable accounting policies and then apply them consistently, to make judgements and estimates that are reasonable and prudent and to prepare the accounts on a going concern basis unless it is inappropriate to presume that the company will continue in business or the charity in operation. The Members of Council are responsible for keeping proper accounting records that disclose with reasonable accuracy at any time the financial position of the company and the charity and to enable them to ensure that the accounts comply with the Companies Act 1985 and the recommendations of the Charity Commissioners. They are also responsible for safeguarding the assets of the company and the charity and hence for taking reasonable steps for the prevention and detection of fraud and other irregularities.

\section{Notice to members of the Society}

The Annual Report is sent to all members of the Society. Pursuant to Section 253(I) (b) of the Companies Act 1989, notice is hereby given that despite the resolution in force that the company elects to dispense with laying the accounts and reports before general meeting every member of the Society has the right to require the laying of accounts and reports before a general meeting. If requested to do so, the Executive Secretary will advise any member of the procedure to be adopted.

\section{Financial support}

Bankers Lloyds Bank plc, 8 Market Place, Faringdon, Oxon, SN7 7HN Girobank plc, Bootle, Merseyside, G1R 0AA Barclays Merchant Services, Marefair, Northampton, NN1 1SG

Investments Branston and Gothard Ltd, 3 Finsbury Square, London, EC2A 1BX

Auditors Critchleys, Chartered Accountants, 10 Marlborough Street, Faringdon, Oxon, SN7 JP 